\title{
Educational Research and Theory in Language Policy: ESL in Quebec Schools
}

\author{
Patsy M. Lightbown
}

I would like to discuss some of the concerns raised in Jim Cummins' paper in relation to another second language learning policy debate: ESL in Quebec schools. Specifically, I would like to address the issue of the necessity of interpreting research findings within the sociopolitical context of relations between majority/minority and dominant/subordinate groups. It is quite difficult to locate the Quebec ESL situation on these sociopolitical continua (majority/minority and dominant/subordinate). Francophones in Canada are members of a minority group. And as recently as ten or fifteen years ago, it would have been possible to say that, in many respects, they were a subordinate minority group relative to English Canadians. That picture has changed considerably, and Frenchspeakers in Quebec have made great strides toward fulfilling their role as a majority group within Quebec, recognizing and realizing their essential equality with English Canadians in other provinces. Recent policy debates on the age at which ESL instruction should begin illustrate that change.

Ten years ago when I was invited to participate in discussions on the possible effects of starting ESL instruction in grade 4 rather than grade 5, the principal concern in the air was that of those who feared that such a policy might threaten Francophone children's development of French. It was easy - and fun - to point out to the audience that the research being cited in support of this fear had been carried out in contexts of total submersion, among children from disadvantaged backgrounds. The tests which were used had been designed for speakers of English as a native language, and the children tested were very likely developing a "subtractive bilingualism": losing their native language, replacing it with English. There was no reason, I argued, to fear that children who had had three or four years of French-language schooling in a French majority environment were at risk for loss of their mother tongue if they got an hour or two of English classes each week! That was about ten years ago.

This year the policy debate on the right age to begin instruction began again. This time it was triggered by a remark by the Minister of Education that he might permit some schools to offer ESL instruction in grade one. Once again, those of us involved in the field of second language learning were called on by concerned parents, school officials, even the media to 
comment on this proposal. Strikingly, with a few exceptions, the concern expressed most often was not whether this might threaten the children's French, but whether this was, in fact, the best - most efficient, reliable, cost-effective - way to ensure that there would be an improvement in their English skills. This kind of concern arises from the confidence of a majority group which, if not dominant, certainly considers itself a strong and confident equal of the other group.

Related to this are the results of a survey which Robert Dole recently carried out at the University of Quebec at Chicoutimi (Dole 1987). In this survey, he was looking for evidence that a defensive nationalist attitude on the part of Quebec university students interfered with their potential bilingual development by setting up negative attitudes toward learning English. What he found did not support such a hypothesis. While $57 \%$ of the students said that, if given an opportunity, they would vote "yes" in a sovereignty-association referendum, and over half said that, if travelling abroad, they would identify themselves as being from Quebec or Quebec, Canada, rather than simply from Canada, and while only ten percent had actually taken an English course in their three years in university, the reason most often given for not taking an English course was that they hadn't had time! Interestingly, this reason for not taking a university English course had not even been listed on Dole's questionnaire. It was a write-in answer by over $35 \%$ of the subjects! As I recall, $93 \%$ of the students intended to improve their English some day, showing evidence of positive attitudes if somewhat unrealistic ideas about how much more time they would have at their disposal after finishing university.

Furthermore, virtually all students said English should be compulsory in Quebec schools, and 53\% thought instruction should begin in grade one! This view seems to reflect confidence that French-speaking Quebecers need not fear the loss of their native language. In light of this sense of confidence, one may ask whether the time has come to relax the legislation which currently prohibits French language schools from offering English immersion and restricts eligibility to English schools to a narrowly defined group of English Canadians. I think that, if one can accept the assumption that the role of French in Quebec should be preserved and reinforced, the answer must be no. It is because of this assumption that the objective of English second language instruction in Quebec is very different from the objective of ESL instruction in Toronto or Vancouver or in bilingual education programs in the United States.

For the Quebec educational system, the objective of ESL instruction is functional bilingualism - the ability to use English for a variety of basic communicative functions. This objective can be achieved without sacrificing a sociopolitically motivated educational principle of a higher order: the development of a French educational system which reinforces the 
sense of majority by ensuring that young francophones have an opportunity to be educated through French and which integrates immigrant populations into this French-language school system. The birth rate among French-speaking Quebecers is falling below the replacement rate, and the French-speaking majority in Quebec can be perpetuated only if the educational system ensures that immigrants develop native-like French language skills (see d'Anglejan 1984). Thus, at a time when a positive sense of self-determination has been achieved, the demographic reality is that French is more threatened now than ever before. Add to this the increasing power of American electronic media, and the necessity of consolidating the role of French becomes even more compelling.

Furthermore, the current generation of school children will be the first in modern Quebec to have the option of using French as their principal language, not only at home and church, but in shops and factories, offices and schools. Working class parents of the children now in Quebec schools have often found it necessary to use English at work and this has sometimes resulted in the development of a variety of French which is full of anglicisms or English words. Middle class parents have often had a part of their education in English because no French-language programs existed in their field of work. The growth of the French university system and the "francization" of the workplace under Law 101 have begun to change this, but new generations of adults will need to consolidate the restoration and revitalization of French.

Nevertheless, for French-speaking Quebecers in Canada and in the larger North American context, knowledge of English is highly desirable, and the functional bilingualism which is the objective for Quebec ESL programs is not being achieved at present by most children. A recent survey by the Ministry of Education of Quebec confirmed what we've all suspected for years, that very few schools offer what the MEQ considers to be the minimum number of hours required for achieving its specific program objectives (Lightbown 1987; Pratte 1987). As this information becomes public, more and more parents are insisting that something be done to give their children opportunities for developing proficiency in English. Various proposals have been made and several experimental programs are being tried. The two which have attracted the most attention are (1) the introduction of ESL from grade one and (2) providing periods of intensive instruction in English rather than spreading ESL instruction out over years and years of 30- to 50-minute lessons.

Researchers in second language learning argue convincingly that it may be necessary to introduce second language exposure in early childhood if the educational objective is to make the child indistinguishable from native speakers of that language (see Krashen, Long and Scarcella 1979). However, the French immersion research suggests that an early start will 
not ensure such mastery of the second language if the students are not exposed to peers who speak that second language as their native or dominant language (Harley and Swain 1984). There is no substantial research to support the superiority of an early start if the instruction is limited to a couple of hours a week or where the objective is basic functional bilingualism (Burstall 1975; Stern 1976). Offering intensive or immersion ESL in the early school years might also be expected to interfere with the establishment of French literacy skills, especially for francophone children who come from homes where such skills are not fostered by educated parents and some immigrant children whose home language is not French (Cummins 1984; Swain 1981). It should be emphasized that research evidence available from a variety of contexts shows that beginning instruction in late childhood or early adolescence is no impediment to the development of high levels of fluency in a second language (Genesee 1987), and individuals who are motivated to continue improving their English can do so by taking advantage of more advanced courses, trips to English-speaking areas, watching English television, and so on.

Intensive ESL instruction at the upper elementary and at the secondary level may permit schools to meet the objective of functional bilingualism without sacrificing the more important sociopolitical objective of ensuring ample opportunity to master the French language. Such programs are being offered in a number of schools and the results are very encouraging. It will be important over the next few years to carry out a program of research which will determine the extent to which these programs are better able to achieve the objective of functional bilingualism in comparison with the more conservative two- to three-hour a week instructional pattern. Very strong claims have been made for the success of these programs, but the context-specific research remains to be done. It has been claimed, for example, that five months of intensive instruction in English at the grade 6 level gives francophone students a level of comprehension in English which is comparable to that of children in grade 6 who have had six years of schooling in an English school (Billy 1980). This claim has not been substantiated by replication studies, but - to my knowledge - no replication studies have been carried out.

The learning outcomes of experimental ESL programs must be investigated and the findings made available to school officials and parents in a way similar to the way in which French immersion research has been made available. For example, the comparison between immersion-type programs where the second language is used as a medium of instruction for mathematics, social science and other subjects, and intensive programs which focus on language learning itself remains to be done. Only research carried out in these contexts can inform us adequately about 
what to expect from such programs. Most new programs fit well within current theories of language acquisition and can be expected to be far superior to the thirty- to fifty-minute a day programs. Nevertheless, the research evidence must be made available as early as possible to prevent a proliferation of "good" programs when more complete evaluations of existing programs might made it possible to develop "better" programs.

In summary, while the goal of improving the level of English skills achieved by Quebec school children is a valid and important one, it must be pursued within the sociopolitical context in which the children's development of their native language is given the highest priority.

\section{REFERENCES}

Billy, L. (1980). Expérimentation d'une nouvelle approche en immersion. Canadian Modern Language Review, 36 (3): 422-433.

Burstall, C. (1975). French in the primary school: The British experiment. Canadian Modern Language Review, 35, 15-32.

Cummins, J. (1984). Bilingualism and special education. Clevedon, UK: Multilingual Matters.

D'Anglejan, Alison. (1984). Language planning in Quebec: An historical overview and future trends. In R.Y. Bourhis (ed.) Conflict and language planning in Quebec. Clevedon, UIC: Multilingual Matters.

Dole, R. (1987). Is Quebec nationalism an obstacle to bilingualism? Paper presented at the TESL Canada Summer Institute, Concordia University, Montreal, 14 July.

Genesee, F. (1987). Learning through two languages. Rowley, MA: Newbury House.

Harley, B. and Swain, M. (1984). The interlanguage of immersion students and its implications for second language teaching. In A. Davies, C. Criper, and A. P. R. Howatt (Eds.), Interlanguage. Edinburgh: University of Edinburgh Press.

Krashen, S.; Long, M.: Scarcella, R. (1979). Age, rate and eventual attainment in second language acquisition. TESOL Quarterly, 13, 573-582.

Lightbown, P. M. (1987). L'enseignement de l'anglais langue seconde au Québec: bilan et prospective. Paper presented at the Premier congrès des sciences de l'éducation de langue française du Canada. Quebec, 14 May.

Pratte, A. (1987). 73 p. cent des élèves du primaire n'ont pas deux heures d'anglais par semaine. La Presse, Montreal, 12 June.

Stern, H. H. (1976). Optimal age: Myth or reality. Canadian Modern Language Review, 32, 283-294.

Swain, M. (1981). Bilingual education for majority and minority language children. Studia Linguistica, 35, 15-32.

\section{THE AUTHOR}

Patsy M. Lightbown is Associate Professor of Applied Linguistics in the TESL Centre at Concordia University. She is the Convenor of the Scientific Commission 
on Second Language Acquisition of AILA (the International Association of Applied Linguistics). Her research focuses on second language acquisition in classroom settings. Publications include "Great Expectations: Second Language Acquisition Research and Classroom Teaching" which appeared in Applied Linguistics in 1985. Her current research projects include investigations of learner language and classroom interaction in intensive ESL courses in French language elementary schools in Quebec. She was a co-director of the 1987 TESL Canada Summer Institute. 